\title{
Habitat suitability of Proboscis monkey (Nasalis larvatus) in Berau Delta, East Kalimantan, Indonesia
}

\author{
TRI ATMOKO ${ }^{1,2, v}$, ANI MARDIASTUTI ${ }^{3 v v}$, M. BISMARK ${ }^{4}$, LILIK BUDI PRASETYO ${ }^{3, v v v, ~}$ \\ ENTANG ISKANDAR ${ }^{5, v v v \varphi}$ \\ ${ }^{1}$ Research and Development Institute for Natural Resources Conservation Technology. Jl. Soekarno-Hatta Km 38, Samboja, Samarinda 75271, East \\ Kalimantan, Indonesia. Tel.: +62-542-7217663, Fax.: +62-542-7217665, `email: three.atmoko@gmail.com, tri_atmoko@apps.ipb.ac.id. \\ ${ }^{2}$ Program of Primatology, Institut Pertanian Bogor. Jl. Lodaya II No. 5, Bogor 16151, West Java, Indonesia \\ ${ }^{3}$ Department of Forest Resource Conservation and Ecotourism, Faculty of Forestry and Environment, Institut Pertanian Bogor. Jl. Lingkar Akademik, \\ Kampus IPB Dramaga, Bogor16680, West Java, Indonesia. Tel.: +62-251-8621677, ^vemail: aniipb@indo.net, ${ }^{\vee v l b p r a s t d p @ a p p s . i p b . a c . i d ~}$ \\ ${ }^{4}$ Forest Research and Development Center. Jl. Gunung Batu No 5, Bogor 16118, West Java, Indonesia \\ 5Primate Research Center, Institut Pertanian Bogor. Jl. Lodaya II No. 5, Bogor 16151, West Java, Indonesia. Tel./fax.: +62-251-8320417, \\ vwrvemail: eiskandar@apps.ipb.ac.id
}

Manuscript received: 1 October 2020. Revision accepted: 13 October 2020.

\begin{abstract}
Atmoko T, Mardiastuti A, Bismark M, Prasetyo LB, Iskandar E. 2020. Habitat suitability of Proboscis Monkey (Nasalis larvatus) in Berau Delta, East Kalimantan, Indonesia. Biodiversitas 21: 5155-5163. Habitat suitability of Proboscis monkey (Nasalis larvatus) in Berau Delta, East Kalimantan, Indonesia. The proboscis monkey (Nasalis larvatus) is an endemic species to Borneo's island and is largely confined to mangrove, riverine, and swamp forests. Most of their habitat is outside the conservation due to degraded and habitat converted. Habitat loss is a significant threat to decrease in monkey's population. Berau Delta is an unprotected habitat of proboscis monkey, lacking in attention and experiencing a lot of disturbances. This study was conducted during April - August 2019; with the aims of identifying proboscis monkey habitat suitability in Delta Berau, East Kalimantan through Species Distribution Modeling (SDM). For SDM, MaxEnt algorithm was used to produce a habitat suitability map based on this species' occurrence records and environmental predictors. We built the models using 208 points of proboscis monkey presence and 12 environment variables within the study area. Model performance was assessed by examining the area under the curve. The variables most influencing the habitat suitability model were the riverine habitat $(60.9 \%)$, distance from the pond $(16.0 \%)$, and distance from the coastline $(5.2 \%)$. The proboscis monkey suitable habitat was predicted to be only 9.32\% (8,726.58 ha) out of total 93,631.41 ha area. The appropriate habitat areas determined were Sapinang Island, Bungkung Island, Sambuayan Island, Saodang Kecil Island, Besing Island, Lati River, Bebanir Lama, Batu-Batu, and Semanting Bay. This study also provides some suggestions for conservation of proboscis monkey, which include local protection of uninhabited islands, participatory ecotourism management, and company involvement in protection and management efforts.
\end{abstract}

Keywords: Colobinae, Species Distribution Model, MaxEnt, primate conservation, riverine forest

Abbreviations: SDM: Species Distribution Model, MaxEnt: Maximum Entropy, VIF: variance inflation factor, FCD: Forest Canopy Density, ROC: Receiver Operating Characteristic, AUC: Area Under the Curve, ULUP: Urban Land-Use Plan.

\section{INTRODUCTION}

Proboscis monkey (Nasalis larvatus Wurmb.) is a unique primate species of old world monkey that belongs to the Colobinae subfamily. Endangered species status A2cd was confirmed by the red list IUCN committee since 2000 (Boonratana et al. 2020) and included in Appendix I of CITES (www.cites.org). The monkeys are protected and highly prioritized for conservation by Indonesian law. However, the monkey population is decreasing due to destruction and loss of their primary habitat in mangrove and riverine forest by various human activities. Since mangrove forests have enormous potential for fish and shrimp pond fisheries, therefore many mangrove forests are being converted into ponds (Atmoko 2015). Likewise, riparian forests and rivers have mainly been used for transportation to Kalimantan's deep inland for a long time ago. Frequent river access is causing riverine forests to quickly degrade to other land use, such as settlements, cultivation, palm oil plantation (Soendjoto and Nazaruddin 2012), tourist facilities (Boonratana 2013), coal loading area and haul route (Atmoko et al. 2012). The proboscis monkey habitat has been lost more than $45 \%$ of the initial habitat of $121,670 \mathrm{~km}^{2}$ (Meijaard and Nijman 2000), with a destruction rate is estimated at $2 \%$ per year (Manansang et al. 2005), and only $9 \%$ of them currently remains in protected areas (Wardatutthoyyibah et al. 2019). This condition has caused the population to decrease by more than $70 \%$ in the past 36 years (Boonratana et al. 2020).

The proboscis monkey is an endemic primate for Borneo and small islands nearby in the vicinity. Distribution of animals covered in three countries, Indonesia (all province of Kalimantan), Malaysia (Sabah, Sarawak), and Brunei Darussalam, which is the largest population found in the Kalimantan region (Phillips and Phillips 2016). Delta Berau is the crucial habitat of proboscis monkey in East Kalimantan with a large population (Atmoko et al. in press). Any aspect of study 
related to proboscis monkey in this location has never been done. Information on the distribution and habitat suitability is the primary data needed to carry out conservation efforts.

Geographic information systems (GIS) have been applied widely in the distribution of wildlife modeling through the Species Distribution Model (SDM) approach (Prasetyo 2017). Several methods used for SDM techniques with the presence-absence dataset are generalized linear models (GLMs) and generalized additive models (GAMs) (Guisan et al. 2002), whereas BIOCLIM (Booth 2018), DOMAIN (Sarquis et al. 2018) and maximum entropy (MaxEnt) (Phillips et al. 2006) use presence data only. The MaxEnt is a most popular tool with excellent performance compared with other SDM methods (Merow et al. 2013), which is through an algorithm equation that estimates the probability distribution for a species occurrence based on environmental variables.

MaxEnt has been used to predict the distribution of primate animals, such as Gorilla beringii beringei (Thorne et al. 2013), Pan troglodytes (Fitzgerald et al. 2018), Alouatta ululata (Filho and Palmeirim 2019), Pongo tapanuliensis (Rahman et al. 2019), Pygathrix nemaeus (Tuan Anh et al. 2019), Rhinopithecus roxellana (Dong 2019), Hylobates moloch (Widyastuti et al. 2020), Semnopithecus entellus (Chetan et al. 2014) and Trachypithecus geei (Thinley et al. 2019). So far, MaxEnt spatial modeling of the distribution of proboscis monkeys has been carried out by (Wardatutthoyyibah et al. 2019) for the whole of Kalimantan. Whereas in this study, the focus will be on the specific area in the Berau Delta, East Kalimantan. This study aims to develop the model of relationships between the existence of the proboscis monkey on the biological components habitat, disturbance from human activity, and climatic or environment variables. The habitat suitability model resulting would be useful for the proboscis monkeys conservation planning at the landscape scale.

\section{MATERIALS AND METHODS}

\section{Study area}

The study was conducted in the Berau Delta, Berau District, East Kalimantan, Indonesia, between $2^{\circ} 17^{\prime}-1^{\circ} 50^{\prime}$ $\mathrm{N}$ and $117^{\circ} 31^{\prime}-118^{\circ} 01^{\prime} \mathrm{E}$ (Figure 1).

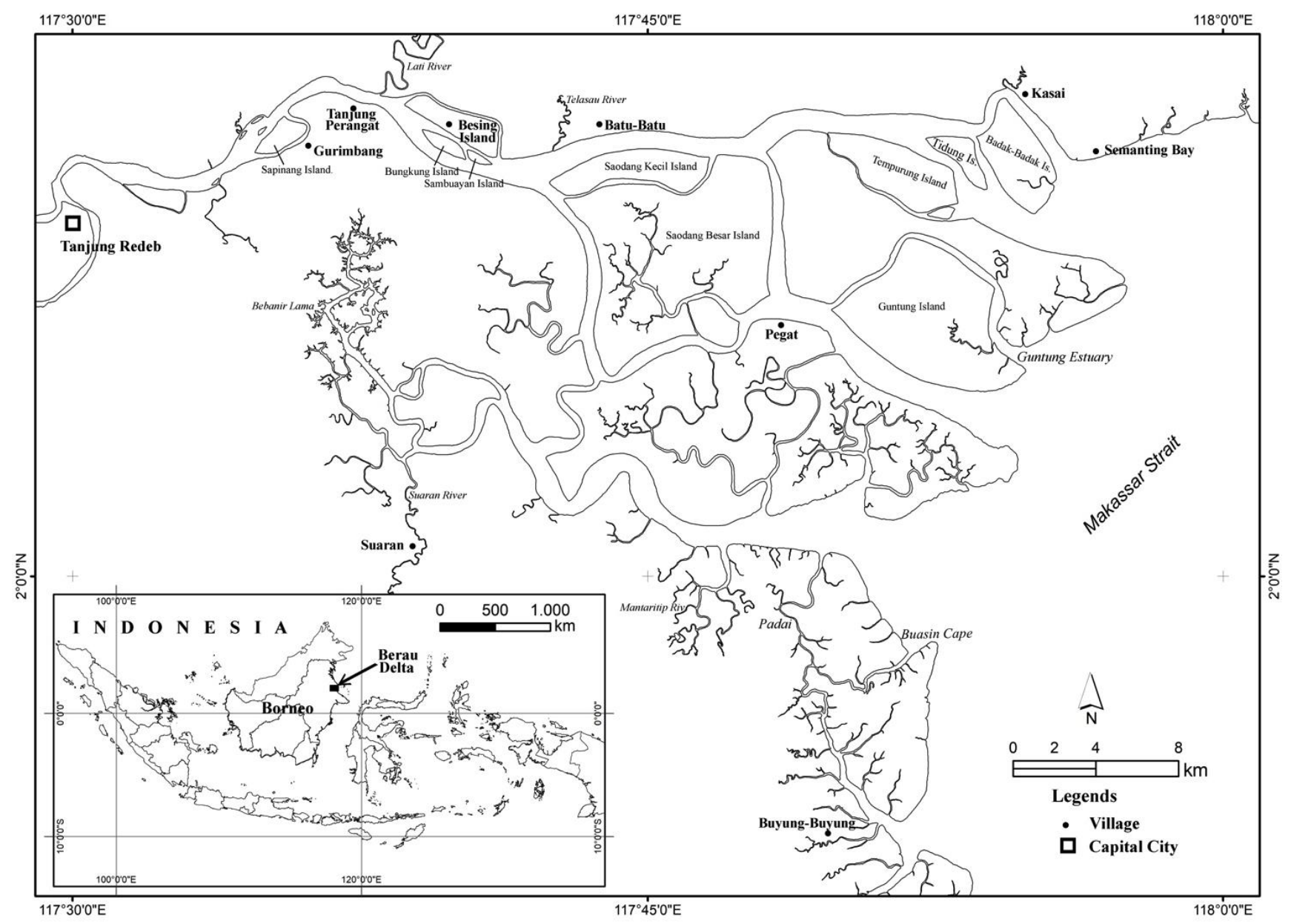

Figure 1. The study site in Berau Delta, East Kalimantan, Indonesia 
In the study area Proboscis monkey's habitat is restricted to the rivers banks and shores. Therefore the study area bordered from rivers and beaches as far as 1,810 $\mathrm{m}$. That distance is the furthest distance of the daily range of proboscis monkey (Boonratana 2000). The total study area after it was bordered was $936.31 \mathrm{~km}^{2}$. The area's annual precipitation in 2019 reached $1,727 \mathrm{~mm}$, mean temperature varied between $23^{\circ} \mathrm{C}$ and $33^{\circ} \mathrm{C}$, and mean relative humidity was $84.9 \%$ (www.bmkg.go.id). The Delta Berau is flat with an altitudinal range from 0 to $290 \mathrm{~m}$ above sea level (asl) and the highest peak at Padai Hill. The forest type within the area is riverine and mangrove forests. The mangrove forest is dominated by Rhizophora mucronata, $R$. apiculata, Bruguiera sp., Sonneratia alba and Avicennia alba, whereas the riverine forest is dominated by Sonneratia caseolaris, Vitex pinnata, Cerbera manghas, Brownlowia argentata, Heritiera littoralis, Syzygium lineatum, and Nauclea officinalis.

\section{Procedures \\ Modeling}

We used the MaxEnt program version 3.4.1 for habitat suitability modeling procedure (Phillips et al. 2006). Prediction with MaxEnt needs presence-only data using environment layers as background. Before running MaxEnt, all raster layers were converted to ASCII with WGS 1984 geographical coordinate reference system, with resolution of cell size of $30 \mathrm{~m}$, and extent on the top (2.32191445435), left (117.313704879), right (118.263989916), and bottom (1.81011847104). We used $75 \%$ of the species occurrence points for the training data, and $25 \%$ as testing/validation of the model. The maximum iterations were set to 1000 or continuous until the convergence threshold at 0.00001 . Jackknife analysis was selected and response curves were created output was set to logistic, while other functions were set to default.

Multicollinearity tests were performed with "faraway" package in $\mathrm{R}$ program where Variance Inflation Factor (VIF) was to determine intercorrelations between independent predictor variables and those variables with VIF> 10 were dropped (Akinwande et al. 2015; Pradhan 2019). The Area Under the Curve (AUC) of the receiving operating curve (ROC) was used to evaluate the model's predictive power. Following Peterson et al. (2011) AUC slabs of $0.5-07$ (denoting poor prediction), 0.7-0.9 (denoting reasonable prediction), and above 0.9 (denoting excellent prediction) were considered. Habitat Suitability Index (HSI) ranging from $0-1$, was categorized into four slabs viz. highly suitable $(>0.6)$, moderately suitable $(0.4-$ $0.6)$, poorly suitable $(0.2-0.4)$, and unsuitable $(<0.2)$ following Yan et al. (2020).

\section{Existence survey}

Boat-based surveys were used to detect point occurrence of proboscis monkeys in April - August 2019. Initial information on the monkey presence was collected from the local community. Furthermore, the survey was conducted on large and selected small rivers along 413.96 $\mathrm{km}$ stretch. To get an accurate geographic point, the positions of monkeys were recorded using "sight 'n go" facility on GPS Garmin CSx60, whose accuracy was further increased by putting the direction and distance of the animals from the observer calculated from laser distance meter. Duplicate data records on the single grid cell $(30 \mathrm{~m} \times 30 \mathrm{~m})$ were removed, to reduce spatial bias (Dong 2019) and the occurrence coordinates were tabulated in a comma-separated value (CSV) format.

\section{Habitat variables}

This study used 12 explanatory variables categorized from biology, disturbance, and physico-environmental variables (Table 1). We used biological factors represented by Forest Canopy Density (FCD), Bare Soil Index (BSI), riverine, and mangrove forest cover. Raster data of biological variables were calculated using data from Landsat satellite imagery $8 \mathrm{OLI}$, path 116 rows 59, which was acquired on 15 July 2019 from https://earthexplorer.usgs.gov/. The images have 11 bands with a $30 \mathrm{~m}$ spatial resolution and a panchromatic band with $15 \mathrm{~m}$ resolution. Raw data images were pre-processed regarding radiometric and atmospheric correction, water, and cloud masking. For Radiometric correction, the ToA (Top of Atmosphere) method (www.usgs.gov) was used, whereas atmospheric corrections used DOS (Dark Object Substation) (Dewi and Trisakti 2016). The Forest Canopy Density (FCD) is a model for mapping and monitoring forest canopy density for characterizing forest conditions and forest degradation indicators (Rikimaru et al. 2002). The FCD was produced by integrating of Scaled Shadow Index (SSI) and Scaled Vegetation Index (SVI). The SVI resulted from Principal Component Analysis (PCA) from Bare Soil Index (BSI) and Advanced Vegetation Index (AVI) (Loi et al. 2017). The BSI value (varying from-1 to +1 ) represented the level of the openness of the land, higher BSI indicating greater openness of the land (Loi et al. 2017)

We used anthropogenic disturbance criteria such as distance (euclidean distance) from settlements, roads, and ponds to record the proboscis monkey occurrence points. Whereas hotspot distribution data represent the effect of forest and land fires during the period 2018-2019, which was obtained from LAPAN hotspot online data (http://modis-catalog.lapan.go.id). Hotspot was interpolated based on its confidence level value. The physicoenvironmental factors were represented by gridded rasters of 30 arc seconds $\sim 1 \mathrm{~km}^{2}$ resolution related to temperature, annual precipitation, wind speed (downloaded from http://www.worldclim.org/), and also the distance from the coastline. Smoothing of above data raster, was carried out by first converting data to point and then interpolated through Inverse Distance Weighted (IDW) method in ArcGIS. 
Table 1. Variables used in the construction of Proboscis monkey's suitable habitat modeling

\begin{tabular}{|c|c|c|c|c|}
\hline Variable & Sources & Unit & Code & VIF value \\
\hline Forest Canopy Density (FCD) & Generate from spatial analysis of Lansat 8 OLI & - & fcd & 2.82 \\
\hline Bare Soil Index (BSI) & Generate from spatial analysis of Lansat 8 OLI & - & bsi & 2.81 \\
\hline Riverine forest & Lansat 8 OLI interpretation & - & riverine_habitat & 4.18 \\
\hline Mangrove forest & Lansat 8 OLI interpretation & - & mangrove_habitat & 6.31 \\
\hline Pond distance & Lansat 8 OLI interpretation & $\mathrm{m}$ & pond_dist & 3.71 \\
\hline Hotspot & LAPAN online hotspot & - & hotspot & 3.42 \\
\hline Road distance & RBI map & $\mathrm{m}$ & road_dist & 2.32 \\
\hline Settlement distance & RBI map & $\mathrm{m}$ & village-dist & 2.54 \\
\hline Coastline distance & RBI map & $\mathrm{m}$ & coastline_dist & 5.30 \\
\hline Annual temperature & WorldClim & ${ }^{\circ} \mathrm{C}$ & temperature & 1.60 \\
\hline Annual precipitation & WorldClim & $\mathrm{mm}$ & precip_annual & 3.22 \\
\hline Wind speed & WorldClim & $\mathrm{m} / \mathrm{s}$ & wind_speed & 2.44 \\
\hline
\end{tabular}

\section{RESULTS AND DISCUSSION}

\section{Proboscis monkey's occurrence}

There were 208 points of occurrence of proboscis monkey which were encountered during the field survey. Usually, proboscis monkeys were active during the day time in the forests and use trees on the riverside for sleeping.

\section{The response curves}

The Forest Canopy Density (FCD) value showed that the habitats of proboscis monkeys range from 0.003 to 80.92 (Figure 2.A). Larger FCD values indicate better forest cover conditions. On the other hand, monkeys' presence decreased along with the increase in the value of the bare soil index (Figure 2,B). The monkeys tend to prefer habitats with good forest conditions. Most of the habitats used were riverine forests, including secondary forests around them, while mangrove habitats were used lesser (Figure 2.C-D). The existence of proboscis monkey against the percentage of hotspots was at the level of 32.16$92.13 \%$ (Figure 2.E). The minimum distance of proboscis monkey to the pond, road, and the central village was $0 \mathrm{~m}$, $0 \mathrm{~m}$, and $30 \mathrm{~m}$. While the monkey's furthest distance by the pond, road, and village center was $16.32 \mathrm{~km}, 13.59 \mathrm{~km}$, and $10.97 \mathrm{~km}$, respectively (Figure 2.F-H). The presence of monkeys increased with increase in distance from the pond area to about $3.70-11.25 \mathrm{~km}$ and then it decreased to 16 $\mathrm{km}$. These interesting results indicate that most of the proboscis monkey population prefers habitats not far from settlements $(0.26-2.40 \mathrm{~km})$ and roads $(0.25-2.30 \mathrm{~km})$. Most of the proboscis monkeys were located at a distance between 19-29 km from the coastline, and area having annual temperature between $27.25-27.91^{\circ} \mathrm{C}$, annual rainfall between 1,845-2,258 $\mathrm{mm} /$ year, and the wind speed ranging from 1.33-1.78 m/s (Figure 2.I-L).

\section{Habitat suitability model}

There was no multicollinearity in all variables used with a VIF value of less than 10 (1.60-6.31) (Table 1) therefore all of these variables were incorporated for further model building. In the MaxEnt results, test AUC value was $0.928 \pm 0.069$ (Figure 3), which was better than random prediction (AUC>0.5), indicating model a good and reasonable model performance. The riverine habitat variable had the highest contribution to the model (60.9\%), followed by distance from the pond $(16.0 \%)$, and distance from the coastline $(5.2 \%)$. The results of the Jackknife test (Figure 4) also validated the importance of riverine habitat in defining the suitable habitat of proboscis monkey. Riverine habitat was the variable that caused the highest gain value when used alone without other variables, meaning that the riverine habitat had beneficial information to predict distribution of proboscis monkey. Further, the explanatory variables had a decrease in gain when the "riverine habitat" variable was excluded from the analysis, meaning the variable had the most information that was not present in other variables.

Based on the habitat suitability index a habitat suitability map was produced with four habitat suitability criteria. The map showed that the suitable habitat was only $9.34 \%$, which was further classified into high, moderate, and poor suitability having areas of $2,751.21$ ha $(2.94 \%)$, $1,594.71$ ha $(1.71 \%)$, and $4,380.83$ ha $(4.69 \%)$, respectively (Figure 5). The suitable habitat spread several locations viz. Sapinang Island, Bungkung Island, Sambuayan Island, Saodang Kecil Island, Besing Island, Lati River, Bebanir Lama, Batu-Batu, and Semanting Bay. These locations are riparian forests, except in Semanting Bay and part of the Bebanir Lama which are mangrove forests. The first four are small islands in the Berau River, located between 16.5$28.0 \mathrm{~km}$ from the coastline, and are still affected by the tides. These islands are not yet inhabited by humans and are separated by rivers with settlements ranging from 200 to $850 \mathrm{~m}$. During river tides, most of the four islands are covered by water; thus, the land is not productive for agriculture. So far, the condition does not indicate any severe habitat disturbance, so it is relatively safe for the conservation of proboscis monkey. Though river waterways surrounding these islands are main route of water traffic from Tanjung Redeb to several islands such as Derawan Island, Maratua Island, and Tarakan Island and it is also a route for coal barge transportation which may add to the riverine disturbance.

Besing Island has an area of 542 ha, $15 \%$ of which have turned into community settlements, the remaining area is in the form of farmer field and riparian forests as a suitability habitat for proboscis monkeys. Likewise, the riverine forest 
in Lati River is generally a highly suitable habitat, except for parts of the river mouth, near roads and settlements that have been converted into fields. The Lati River average width is $35 \mathrm{~m}$ and is relatively rarely used as a water transportation route because the road network is well connected. During the study, some people were found doing recreational canoeing for fishing/angling during holidays, but there is no hunting disturbance at this location. Bebanir Lama is located relatively far from the settlement $(7.5 \mathrm{~km})$, so it has a little anthropogenic disturbance. Interestingly this location is $27 \mathrm{~km}$ from the coastline, but has mangrove patches and is affected by salinity; therefore, it was known that the habitat of the proboscis monkeys was extended from riparian forests to mangrove forests. The proboscis monkey habitat in the Batu-Batu Village area is along the banks of the Berau River, which is fragmented by settlements and coal mining activities. The monkey habitat in Semanting Bay is along the Semanting River and the coastal area dominated by the Sonneratia alba stand; however, oil palm plantations have isolated the habitat.

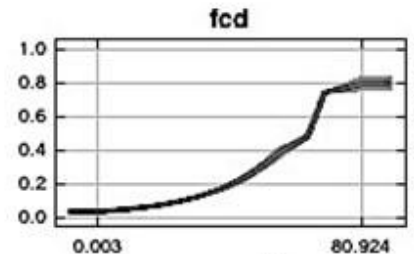

(a)

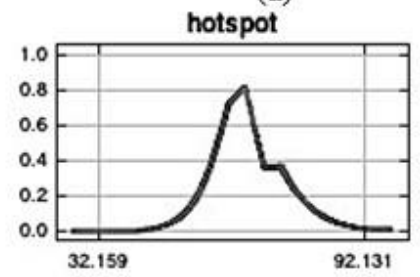

(e)

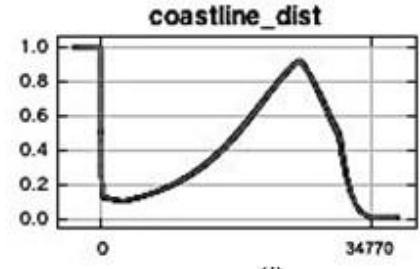

(i)

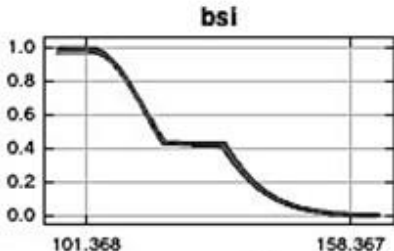

(b)

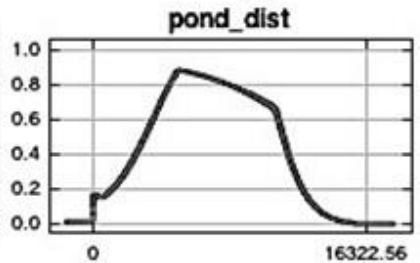

(f)

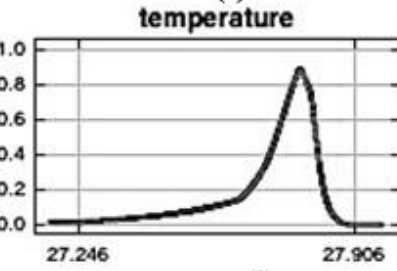

(j)

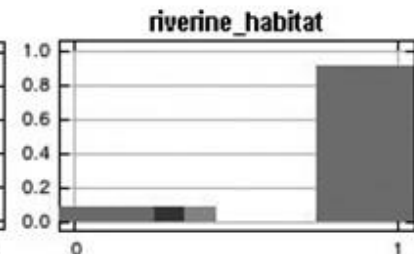

(c)

road_dist

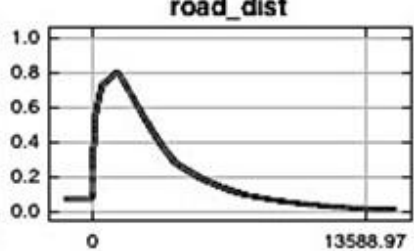

(g)

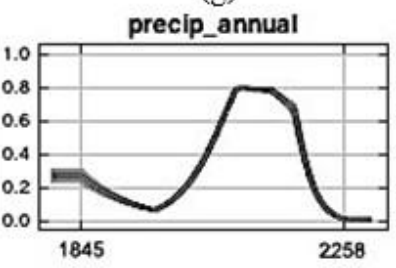

(k)

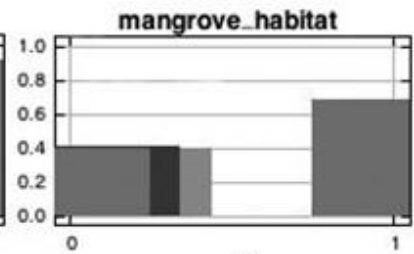

(d)

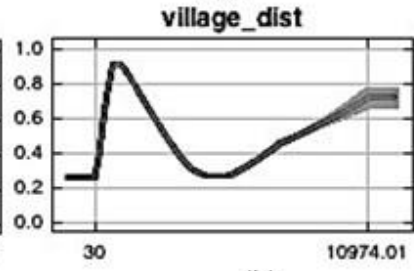

(h)

Figure 2. The response curves showing response of habitats of proboscis monkey to predictor variables.

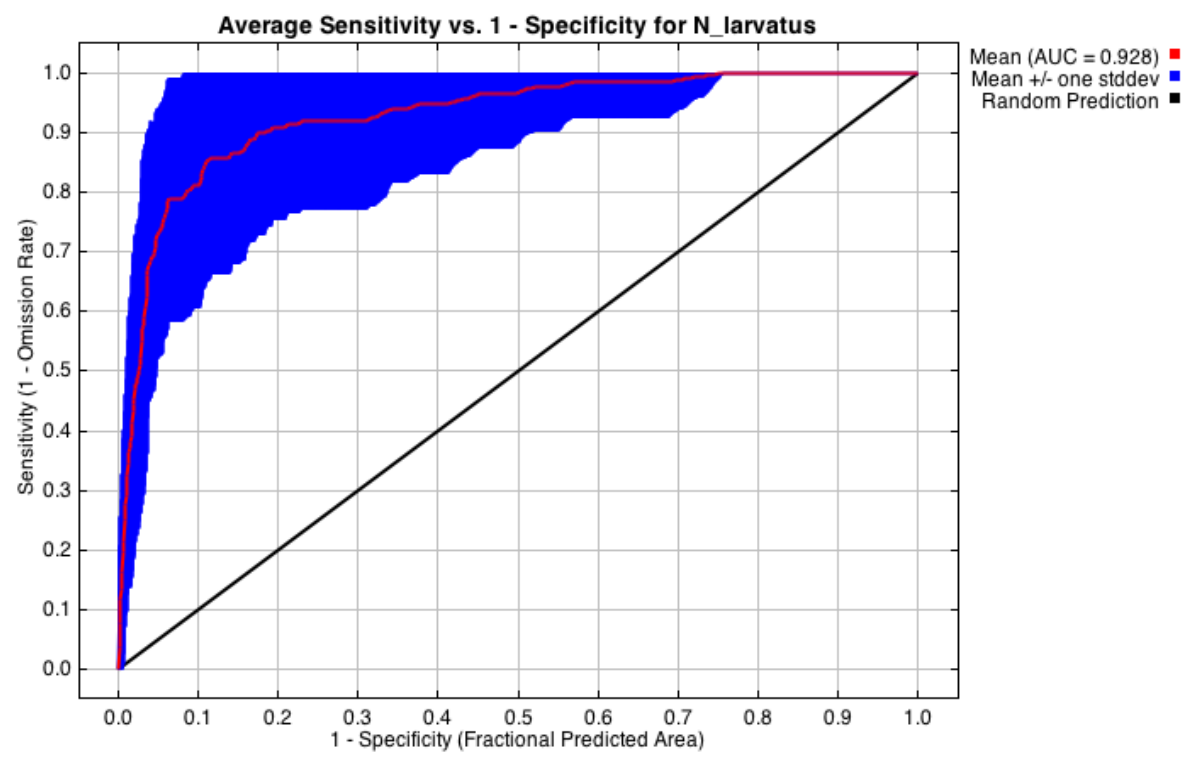

Figure 3. The Receiver Operating Characteristics Curve (ROC) and the value of Area Under Curve (AUC) for predicted distribution of proboscis monkey 


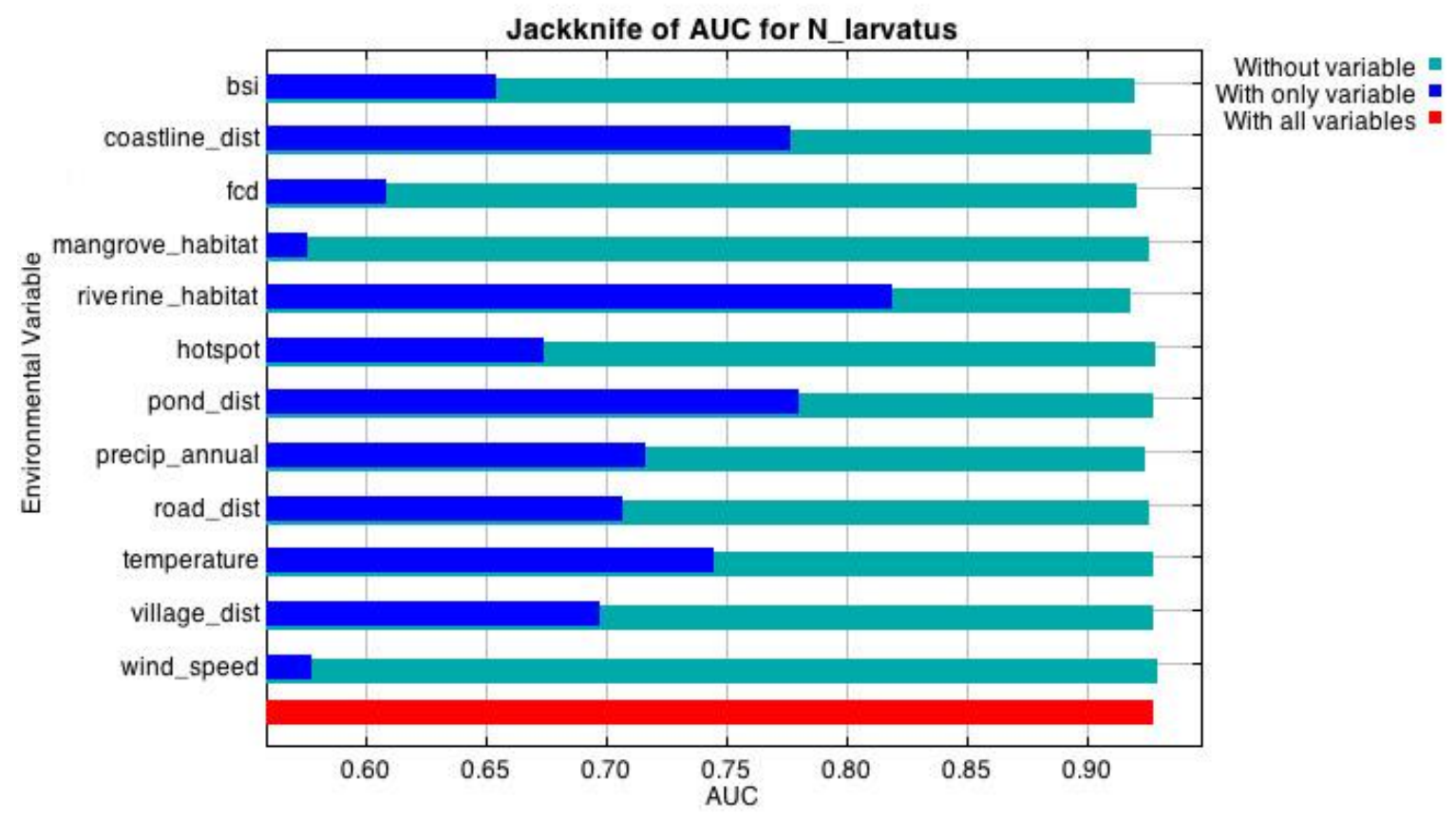

Figure 4. Jackknife test results and its impact on Area Under Curve (AUC) for habitat suitability modeling of proboscis monkey

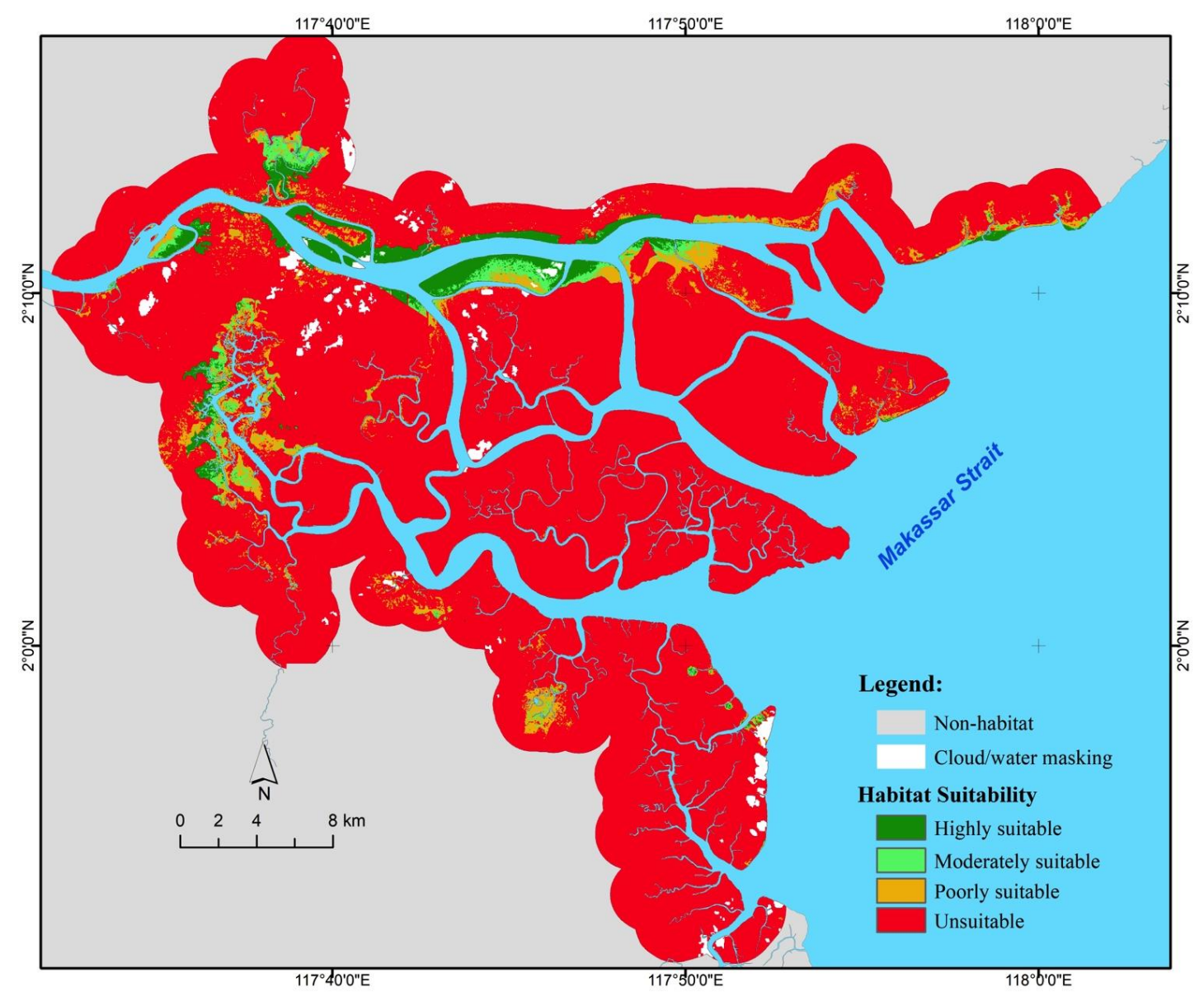

Figure 5. Habitat suitability index (HSI) of Proboscis monkey in Berau Delta, East Kalimantan, Indonesia 


\section{Discussion}

The results of this study and Wardatutthoyyibah et al. (2019) both produced excellent predictions for modeling of proboscis monkey habitat suitability, although AUC value in this study was slightly lower. The excellent predictions mean that the model has a high degree of accuracy to produce habitat preferences information (Franklin and Jennifer 2009). One of the advantages of using MaxEnt is that it can predict species' geographic distribution by using species presence and variable (feature) data only, which affect pixel-based species presence (Phillips et al. 2006). Pixels that have the presence of species and their environment variables will have a maximum value of 1 , while pixels without species presence data will have a value of 0 . Based on a sample of background pixels and pixels of species presence, MaxEnt will perform a logistic regression analysis by randomizing these pixel samples to model distribution species predictions spatially (Phillips et al. 2006).

The riverine habitat variable had the most information in generating a model, while other variables did not possess that information. The riparian forest is reported as one of the main habitat types of proboscis monkeys (Phillips and Phillips 2016). The river banks generally area formed by alluvial soil, which is well-known clay texture, with high organic and nitrogen content, good soil structure and thus possessing high productivity (Loi 2008), a high diversity of plants (Katovai et al. 2015), variety of forest structure and composition and regeneration pattern (Maingi and Marsh 2006). The high diversity of plant species in the habitat provides varied food plant species for proboscis monkey and offers many alternatives to many balanced nutrition sources (Bismark 2009).

The plant species richness in riverine habitat is a result of its location in a transitional zone (ecotone) between a wet riverbank and dry land thus having representation of species from both forest types. The frequency of flood affects the variety of plant species richness in riparian forests. The riverine forest with irregular flooded has a higher plant diversity and more abundant opportunistic species having more environmental plasticity (Budke et al. 2008). That shows the plant species develop abilities to survive from inundation conditions on the habitat. Furthermore, the distribution and abundance of plant species are also related to topographic variations. Reportedly the riverine forests have more rich plant species than lower montane forests and hill forests (Katovai et al. 2015).

The parameters of altitude, slope, and distance from the river were not included in this study for two reasons. First, the gradient in elevation of the study area's potential habitat is narrow (0-40 m a.s.1) and relatively flat. Second, the surveys only detected proboscis monkeys from riverbanks and shorelines because proboscis monkey' movement is not far from the coastline (Suwarto et al. 2016) and riverbanks (Matsuda et al. 2018). So that involving these three factors has potentially lead to bias in the analysis. This study is different from the study by Wardatutthoyyibah et al. (2019), which uses altitude as one of its parameters. That is possible because the study area is broad and includes the coastline to the river upstream in Kalimantan with an altitude range of 0-350 $\mathrm{m}$ a.s.1. Her study showed that the altitude variable had the highest contribution to the habitat suitability model of the proboscis monkey.

Distance from the pond was the second variable that most influenced the suitability of the proboscis monkey habitat. Study of Wardatutthoyyibah et al. (2019) also showed that the pond's distance was among the top three factors that contributed most to the suitability of proboscis monkey habitat. Based on the 2009 ALOS image, more than 4,600 ha of mangrove forest has been transformed into pond area on the main island of the Berau Delta (Hasnawi et al. 2015) and based on the interpretation of Landsat satellite imagery 8 OLI in 2019 , the total area of the pond has increased 2.5 times to 11,500 ha. As indicated by the opening of new ponds during the field survey, the pond's area may continue to increase. The conversion of mangrove forests into ponds area is one of the biggest threats to the proboscis monkey habitat. This habitat threatening condition has also been reported from Balikpapan Bay (Atmoko et al. 2012) and Mahakam Delta (Atmoko 2015).

Distance from the coastline was the third most influential variable in the model which could possibly be related to the salinity level of seawater. The salt, both sea and mountain salt, are essential mineral sources for wild mammals (Blake et al. 2011). Large herbivores require adequate quantities of both essential macro-minerals and trace minerals from environment for healthy body functions (Suttle 2010; Yoshihara et al. 2013; Atmoko 2016; Uniyal et al. 2018). While macro-minerals are required by animals in large quantities, excess of trace elements is known to cause poisoning in animals (Counotte et al. 2019). The large mammals often visit salt licks to adequate mineral intake (Ajayi and Ogunjobi 2016); meanwhile, proboscis monkeys use habitats around the coastline or near riparian estuary with certain salinity levels. In this study, proboscis monkeys' presence decreased along with decreasing salinity levels in the waters due to the coastline's distance. This may be a strategy of proboscis monkeys to avoid trace minerals in excessive amounts both in water and food plants.

\section{Conservation implication}

Riparian forests on the river banks are the primary habitat of proboscis monkeys and an important corridor for the other animal wildlife. Government Regulation (Peraturan Pemerintah) of the Republic of Indonesia number 38 of 2011 also stipulates that river border areas are protected areas for buffer zones between rivers and land ecosystems, so that riverine ecosystem functions are not hampered by human activities. The widths of buffer zones of large and small streams are $100 \mathrm{~m}$ and $50 \mathrm{~m}$ respectively. On another side, base on the Urban Land-Use Plan/ULUP (Rencana Tata Ruang Wilayah) of the Berau District, the river border area has designated as a protected area. Unfortunately, these regulations could not be implemented until now to the level of what is required. Therefore, promoting the importance of safeguarding 
riverbank forests needs to be encouraged and as well, the role of law enforcement needs to be emphasized.

The uninhabited islands in the Berau river that are inhabited by proboscis monkey viz. Sapinang Island, Bungkung Island, Sambuayan Island, and Saodang Kecil Island are needed to be protected locally. It is suggested that village regulations should determine and demarcate the protected areas of the proboscis monkey. An example that could be followed is the traditional protection to proboscis monkey provided by the inhabitants of Pagat Batumbuk Village in Saodang Kecil Island.

Proboscis monkey habitat in Besing Island and BatuBatu Village are close to settlements, so management needs to be done in a participatory manner with local communities. Non-Government Organizations (Lembaga Swadaya Masyarakat-LSM) and Community BasedOrganizations (Kelompok Swadaya Masyarakat-KSM) have been carrying ecotourism activities in proboscis monkey habitats. An example is the LSM Kanopi, in collaboration with KSM Perangat Timbatu has been developing mangrove and proboscis monkey ecotourism in Batu-Batu Village, whereas Tim Pengelola Mangrove Semanting (TPM) is working in Teluk Semanting Village. The boardwalks and shelters have been built to support ecotourism activities, with financial support from the Tropical Forest Conservation Act (TFCA), Kalimantan Program. This ecotourism destination is more accessible because it is traversed by road and river transportation lane from the capital of Berau District to the underwater tourist destination on Derawan Island, one of the leading tourist destinations in Berau District. KSM Perangat Timbatu has a water resources monitoring team in Batu-Batu Village which patrols twice a month surveilling for the protection from illegal fishery and use of fish poison and electricity for catching fishes. Along with the implementation of mangrove and proboscis monkey ecotourism, the team also monitors local status of monkeys.

Proboscis monkey habitat in Bebanir Lama and Semanting Bay is bordered by forest plantation and oil palm concession. Companies should be involved in the ecological reserve, through the protection of endangered species, proboscis monkeys. The Corporate Social Responsibility program can be used to protect and habitat rehabilitation activities. That issue is in line with the recommended actions for proboscis monkeys as per Population and Habitat Viability Assessment document, which involves plantation of oil palm to protect riparian forests which would maintain monkey corridor while the palm oil plantations would receive minimal impact of flood due to presence of riparian forest buffer (Manansang et al. 2005). While promoting forest management the participating companies could adopt sustainable forest management practices which by default incorporates balancing ecological (e.g. habitat conservation, minimizing anthropogenic impact etc.), economic, and socio-cultural aspects, thus helping in a way to conserve endangered species, such as proboscis monkey.

\section{ACKNOWLEDGEMENTS}

We express our sincere thanks to the head of Balitek KSDA, Dr. Ishak Yassir, for his support and Yayasan Arsari Djoyohadikusumo for benefitted funding to this research. We are grateful to Ridi Haidir (KSM Perangat Timbatu) and Ibrahim (Yayasan Kanopi) for his support along with our field study in Berau. We particularly thank the staff of GIS Laboratory, IPB University, Indonesia especially Doni, Oci, and Yoga. We also thank our field research assistants, especially Priyono, Ali, Majid, and Sadarman.

\section{REFERENCES}

Ajayi SR, Ogunjobi JA. 2016. Composition of large mammals day-time visitation to salt lick sites inside Kainji Lake National Park, Nigeria. Ife J Sci 17: 335-340.

Akinwande MO, Dikko HG, Samson A. 2015. Variance Inflation Factor: As a condition for the inclusion of suppressor variable(s) in regression analysis. Open J Stat 5: 754-767.

Atmoko T. 2015. The habitat and distribution of Proboscis Monkey in Mahakam Delta, East Kalimantan. In: Alikodra HS, Bismark M, Sondjoto MA (eds.). The Struggle Against Extinction. IPB Press, Bogor. [Indonesian]

Atmoko T. 2016. State of the art and conservation effort of Proboscis Monkey (Nasalis larvatus) in Kalimantan. In: Proceeding of Balitek KSDA Research Results Seminary. Balitek KSDA, Balikpapan. [Indonesian]

Atmoko T, Ma'ruf A, Rinaldi SE, Sitepu BS. 2012. The distribution of Proboscis Monkey (Nasalis larvatus Wurmb.) in Balikpapan Bay, East Kalimantan. In: Proceedings of Balitek KSDA Research Results Seminary. Balitek KSDA, Balikpapan. [Indonesian]

Bismark M. 2009. Conservation Biology of Proboscis monkey (Nasalis larvatus). Puslitbang Hutan dan Konservasi Alam, Bogor. [Indonesian]

Blake JG, Mosquera D, Guerra J, Loiselle BA, Romo D, Swing K. 2011. Mineral licks as diversity hotspots in lowland forest of eastern Ecuador. Diversity 3: 217-234.

Boonratana R. 2000. Ranging behavior of proboscis monkeys (Nasalis larvatus) in the Lower Kinabatangan, Northern Borneo. Intl $\mathrm{J}$ Primatol 21: 497-518.

Boonratana R. 2013. Fragmentation and its significance on the conservation of proboscis monkey (Nasalis larvatus) in the Lower Kinabatangan, Sabah (North Borneo). In: Marsh LK, Chapman CA. (eds.). Primates in Fragments: Complexity and Resilience, Developments in Primatology: Progress and Prospects. Springer, New York.

Boonratana R, Cheyne SM, Traeholt C, Nijman V, Supriatna J. 2020. Nasalis larvatus. IUCN Red List Threat. Species 2020. DOI: 10.2305/IUCN.UK.2020-2.RLTS.T14352A17945165.en. [August 10, 2020].

Booth TH. 2018. Why understanding the pioneering and continuing contributions of BIOCLIM to species distribution modelling is important. Austral Ecol 43: 852-860.

Budke JC, Jarenkow JA, Oliveira-Filho AT de. 2008. Tree community features of two stands of riverine forest under different flooding regimes in Southern Brazil. Flora 203: 162-174.

Chetan N, Praveen KK, Vasudeva GK. 2014. Delineating ecological boundaries of Hanuman Langur species complex in Peninsular India using MaxEnt modeling approach. PLoS ONE 9(2): e87804. DOI: 10.1371/journal.pone.0087804.

Counotte G, Holzhauer M, Carp-van Dijken S, Muskens J, Van der Merwe D. 2019. Levels of trace elements and potential toxic elements in bovine livers: A trend analysis from 2007 to 2018. PLoS ONE 14(4): e0214584. DOI: 10.1371/journal.pone.0214584.

Dewi EK, Trisakti B. 2016. Comparing atmospheric correction methods for Landsat OLI data. Int J Remote Sens Earth Sci 13: 105-120.

Dong X. 2019. Suitable habitat prediction of Sichuan Snub-nosed Monkeys (Rhinopithecus roxellana) and its implications for 
conservation in Baihe Nature Reserve, Sichuan, China. Environ Sci Pollut Res 26: 32374-32384.

Filho RF, Palmeirim JM. 2019. Potential distribution of and priority conservation areas for the endangered caatinga howler monkey Alouatta ululata in North-Eastern Brazil. Oryx. DOI: 10.1017/S0030605318001084.

Fitzgerald M, Coulson R, Lawing AM, Matsuzawa T, Koops K. 2018. Modeling habitat suitability for chimpanzees (Pan troglodytes verus) in the Greater Nimba Landscape, Guinea, West Africa. Primates 59: 361-375.

Franklin J, Jennifer JM. 2009. Mapping Species Distributions spatial inference and prediction. Cambridge University Press, Cambridge, UK.

Guisan A, Thomas C. Edwards J, Hastie T. 2002. Generalized linear and generalized additive models in studies of species distributions: Setting the scene. Ecol Model 157: 89-100.

Hasnawi, Indra A, Asaad J, Mustafa A. 2015. Characteristics of existing pond land in Derawan Island District, Berau District, East Kalimantan Province. J Riset Akuakultur 10: 593-608. [Indonesian]

Katovai E, Katovai DD, Edwards W, Laurance WF. 2015. Fores structure, plant diversity and local endemism in a highly varied New Guinea landscape. Trop Conserv Sci 8: 284-300.

Loi DT, Chou T, Fang Y. 2017. Integration of GIS and remote sensing for evaluating Forest Canopy Density Index in Thai Nguyen Province, Vietnam. Int J Environ Sci Dev 8: 539-542.

Loi N Van. 2008. Use of GIS Modelling in Assessment of Forestry Land's Potential in Thu Thien Hue Province of Central Vietnam. [Dissertation]. Georg-August-University, Göttingen.

Maingi JK, Marsh SE. 2006. Composition, structure, and regeneration patterns in gallery forest along the Tana River near Bura, Kenya. For Ecol Manag 236: 211-228.

Manansang J, Traylor-Holzer K, Reed D, Leus K. 2005. Indonesian Proboscis Monkey Population and Habitat Viability Assessment: Final Report. IUCN/SSC Conservation Breeding Specialist Group, Apple Valley, MN

Matsuda I, Abram NK, Stark DJ, Sha JCM, Ancrenaz M, Goossens B, Lackman I, Tuuga A, Kubo T. 2018. Population dynamics of the proboscis monkey Nasalis larvatus in the Lower Kinabatangan, Sabah, Borneo, Malaysia. Oryx. 54: 583-590. DOI: 10.1017/S0030605318000467.

Meijaard E, Nijman V. 2000. Distribution and conservation of the proboscis monkey (Nasalis larvatus) in Kalimantan, Indonesia. Biol Conserv 92: 15-24.

Merow C, Smith MJ, Silander JA. 2013. A practical guide to MaxEnt for modeling species' distributions: what it does, and why inputs and settings matter. Ecography 36: 1058-1069.

Peterson AT, Soberon J, Pearson RG, Anderson RP, Martinez-Meyer E, Nakamura M, Araujo MB. 2011. Ecological Niches and Geographic Distributions. Princeton University Press, Princeton, NJ.

Phillips Q, Phillips K. 2016. Field Guide to The Mammals of Borneo and Their Ecology. John Beaufoy Publishing Ltd., England.

Phillips S., Anderson R., Schapire R. 2006. Maximum entropy modeling of species geographic distributions. Ecol Model 190: 231-259.

Pradhan P. 2019. Testing equivalency of interpolation derived bioclimatic variables with actual precipitation: A step towards selecting more realistic explanatory variables for species distribution modelling. Res J Chem Environ 23: 38-41.

Prasetyo LB. 2017. Landscape Ecology Approach for Biodiversity Conservation. Faculty of Forestry, IPB University, Bogor. [Indonesian]

Rahman DA, Rinaldi D, Kuswanda W, Siregar R, Ch FN, Hakim F, Arief H, Putro HR. 2019. Determining the landscape priority and their threats for the critically endangered Pongo tapanuliensis population in Indonesia. Biodiversitas 20: 3584-3592.

Rikimaru A, Roy PS, Miyatake S. 2002. Tropical forest cover density mapping. Trop Ecol 43: 39-47.

Sarquis JA, Cristaldi MA, Arzamendia V, Bellini G, Giraudo AR. 2018. Species distribution models and empirical test: Comparing predictions with well-understood geographical distribution of Bothrops alternatus in Argentina. Ecol Evol 8: 10497-10509.

Soendjoto MA, Nazaruddin. 2012. Distribution of the Proboscis Monkey (Nasalis larvatus) in Balangan District, South Kalimantan, Indonesia. Tigerpaper 39: 1-7.

Suttle NF. 2010. Mineral Nutrition of Livestock, 4th Edition. 4th ed. CABI Publishing, Wallingford, UK.

Suwarto, Prasetyo LB, Kartono AP. 2016. Suitability habitat of proboscis monkey (Nasalis larvatus Wurmb, 1781) in mangrove forest Kutai National Park, East Kalimantan. Bonorowo Wetlands 6: 12-25. [Indonesian]

Thinley P, Norbu T, Rajaratnam R, Vernes K, Wangchuk K, Choki K, Tenzin J, Tenzin S, Kinley, Dorji S, Wangchuk T, Cheda K, Gempa. 2019. Population abundance and distribution of the endangered golden langur (Trachypithecus geei) in Bhutan. Primates 60: 437-448.

Thorne JH, Seo C, Basabose A, Gray M, Belfiore NM, Hijmans RJ. 2013. Alternative biological assumptions strongly influence models of climate change effects on mountain gorillas. Ecosphere 4 (9): 108. DOI: 10.1890/ES13-00123.1.

Tuan Anh N, Duc Minh L, Viet Hung P, Thi Duyen V. 2019. Modeling the red-shanked douc (Pygathrix nemaeus) distribution in Vietnam using Maxent. VNU J Sci Earth Environ Sci 35: 61-71.

Uniyal S, Ashwin K, Mishra A, Sahoo JK, Paladan V. 2018. Importance of micro minerals in reproductive performance of farm animals. Intl $\mathbf{J}$ Curr Microbiol Appl Sci 7: 3584-3589.

Wardatutthoyyibah, Pudyatmoko S, Subrata SA, Imron MA. 2019. The sufficiency of existed protected areas in conserving the habitat of Proboscis Monkey (Nasalis larvatus). Biodiversitas 20: 1-10.

Widyastuti S, Perwitasari-Farajallah D, Prasetyo LB, Iskandar E, Setiawan A. 2020. Maxent modelling of habitat suitability for the endangered Javan Gibbon (Hylobates moloch) in less-protected Dieng Mountains, Central Java. IOP Conf Ser Earth Environ Sci 457: 012014. DOI: 10.1088/1755-1315/457/1/012014

Yan H, Feng L, Zhao Y, Feng L, Wu D. 2020. Prediction of the spatial distribution of Alternanthera philoxeroides in China based on ArcGIS and MaxEnt. Glob Ecol Conserv 21: e00856. DOI: 10.1016/j.gecco.2019.e00856.

Yoshihara Y, Mizuno H, Ogura S, Sasaki T, Sato S. 2013. Increasing the number of plant species in a pasture improves the mineral balance of grazing beef cattle. Anim Feed Sci Technol 179: 138-143. 